\title{
Rural Youth Employment through Transitional Beekeeping in Jimma Zone, Ethiopia
}

\author{
LALISA WENDIMU BIYENA*
}

\begin{abstract}
Beekeeping is an interesting off farm practice for low-resource people that provide employment opportunities to rural youth in developing countries like Ethiopia. The study aimed to improve jobless youth income through beekeeping, create access to profitable honey market and contribute to climate change mitigation. Both purposive and random sampling procedure was used to select sample beekeeper and study area. It is case study data on 105 rural youths sampled from two districts and two kebele administrations representing traditional beekeeping farming in Jima Zone of Ethiopia. Descriptive statistics used to analyze quantitative data collected whereas on spot analysis also used to analyze qualitative data such as text data from interview transcripts. The results show that introduced transitional chefeka hive contributed significantly to the youths' employment that relief them from dependency and low self-esteem in the community. On average hive productivity was increased from $6 \mathrm{~kg}$ to $17.4 \mathrm{~kg}$ per hive and revenue generated encouraged the groups increase colony number in double fold and earn about US 6828.69 from honey and beeswax in one year. Moreover, accumulated revenue inclined them to start other income source activity besides beekeeping enterprise. Moreover, youth were found to be significantly more aware and responsible to mitigate recurrent climate change. Therefore, development interventions had better give emphasis to capacitate bee extension support system.
\end{abstract}

KEYWORDS

Beekeeping, Chefeka beehive, youth, climate change, Jima Zone

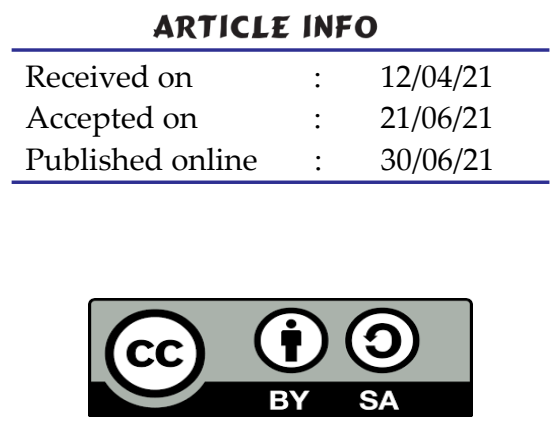

\section{INTRODUCTION}

$\mathrm{B}$ eekeeping is the art of managing honeybee colonies for economic benefits (Ahmad et al, 2007). It is particularly suitable for hard-up landless and low- income, low-resource individuals and groups. Ahmad and Ahmad and Pratap (2009) reported that beekeeping requires minimal start up investment and generally yields profits within the first year of operation. It contributes significantly to securing sustainable livelihoods by assisting in transforming vulnerabilities into security (Ahmad et al, 2007). In addition to the direct income from bee products, beekeeping enterprise stimulates various sectors within a society like hive carpentry, honey trading, and hiring of bee colonies for pollination, and other bee value addition (Chazovachii et al 2013 and Singh et al 2016).

Transitional Chefeka beehive is useful and important for lowincome people and forest resource conservation. It does not require precise specification, advanced high cost wood machines, and casting mold. Therefore, it is technically, economically and environmentally feasible to smallholder beekeepers. This affordable bee hives can be made from nontimber local materials Bamboo (Arundinaria alpine), shembeko (Arundinaria donax), Shimel (Oxytenathera abyssinica) and eucalyptus trees branches, ((Nuru et al, 2002). Deforestation is the most widely recognised, vital factors responsible for the degradation of the environment globally ((Mcs and
Machangu, 2008). Loss of trees has only negative implications for beekeepers: loss of food for bees, loss of nesting sites for bees, loss of materials for building hives, loss of places to keep hives. But transitional Chefeka bee hives that does not need timber contributes to climate change mitigation at local level. Youth unemployment is a problem that affects most countries. The ability of youth to engage in productive activities has both social and economic consequences for an economy ((Nzinga et al, 2012). Youth employment presents a particular challenge to Ethiopia; the country faces growing youth landlessness in rural areas and insignificant rural job creation, potentially leading to an increase in migration to urban areas (Anonymous, 2007 and Dorosh and S2010) leading to urban decay.

In Ethiopia, there has been a significant increase in educational attainment; however, there has not been as much job creation to provide employment opportunities to youth job seekers ((Nzinga et al, 2012). The implementation of the programs at creation of job has not focus much attention into beekeeping as an enterprise. More so, access to land in the rural area is becoming unattainable due to population growth particularly in Jimma Zone. As a result, this study aimed to improve rural unemployed youth income through beekeeping, improve access to profitable bee products market and contribute to climate change mitigation at local level.

\footnotetext{
${ }^{1}$ Oromia Agriculture Research Institute Research, Holeta Bee Research Center, P.O.Box: 22, Holeta, Ethiopia

"Corresponding author email: lalisa2020@gmail.com
} 


\section{MATERIALS AND METHODS}

\section{Description of the study area}

The study was conducted in Goma and Mana Districts of Jimma Zone, Ethiopia. Jima zone is one of the major coffee growing areas of Oromia region well-endowed with natural resources contributing significantly to the national economy of the country. Goma and Mana located $465 \mathrm{~km}$ and $403 \mathrm{~km}$ south west of Addis Ababa, respectively. Goma is one of coffee biodiversity centers found in Ethiopia and one of the most densely populated district in Jimma Zone with a size of $96,361.72$ ha $(94.4 \mathrm{~km} 2)$ including the two coffee state farms which cover an area of 2704 ha ((IPMS, 2007).

The average annual rainfall of the Goma and Mana districts is $1524 \mathrm{~mm}$ and $1467 \mathrm{~mm}$ with low variability, respectively. It is bimodality distributed in which the small rains are from March to April and the main rainy season from June to October. Altitude in the Goma and Mana districts ranges from 1380 to 1680 and 1387 to 2870 meters above sea level, respectively. According to data collected from Mana administration office (2007) it is situated between $7^{\circ} 46.5$ and $7^{\circ} 51.5$ in North while $36^{\circ} 40$ and $36^{\circ} 42$ in East. Mana has annual rainfall of $1467 \mathrm{~mm} /$ annum with a minimum and maximum temperature of $13^{\circ} \mathrm{C}$ and $24.8^{\circ} \mathrm{C}$ respectively.

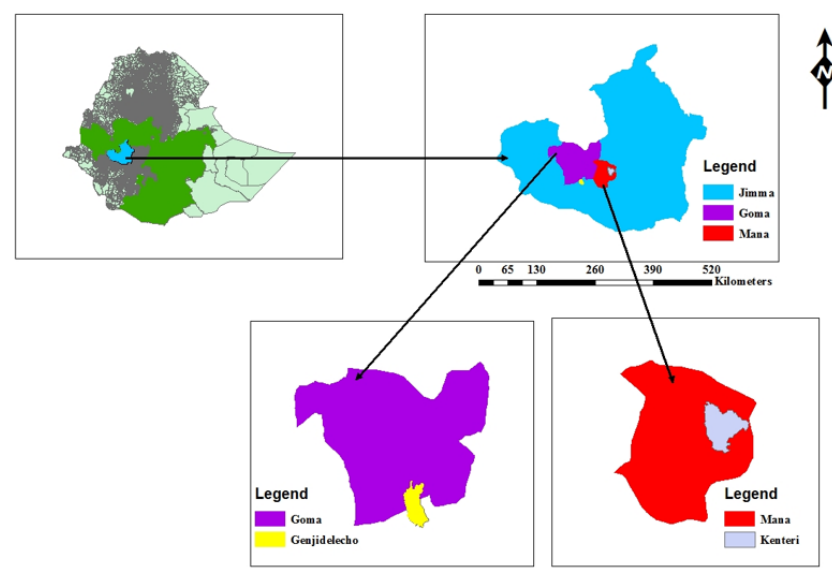

Fig. 1: Map of the study area

Both districts occupy loamy soils with production of coffee, cereals and vegetables. Coffee accounts for $80 \%$ of the production and an important cash crop in the area. Coffee is grown in these districts under shade trees. These areas have potential for conventional agriculture and most of the population derives its livelihood from the forests/coffee. High forest, woodland, riverine, shrubs and bush, and manmade forests are all found in the zone. Beekeeping is, therefore, a vital source of income to the residents of this Zone. Teff, maize and honey production are another sources of cash after coffee.

\section{Sampling Method}

In this study cross sectional survey used in order to assess the overall activities at one shot. The study employed sampling procedures having both purposive and random selection procedures to identify the sample respondents. On the first stage,
Goma and Mana Districts of Jima Zone were purposively selected based on the criteria of having large number of participants in beekeeping, potential area for beekeeping, abundance of honey-bee colonies, and availability of common bee forage. Then, one kebele from Goma (Gangidelecho PA) and Mana (Kenteri PA) were selected randomly from each district. On the second stage, 105 respondents (57 youths from group members and 48 control individuals) were selected using simple random sampling method to collect data in both districts. To determine the total sample size, the following simplified formula were employed at $90 \%$ level of confidence interval, degree of variability $=0.5$ and level of precision $=8 \%(0.08)$.

$$
\begin{aligned}
& n=\frac{(z)^{2} *(p)(q)}{(e)^{2}} \\
& n=\frac{(1.64)^{2} *(0.5)(0.5)}{(0.08)^{2}}=105
\end{aligned}
$$

Where: $\mathrm{z}=$ Value for selected alpha level of 0.25 in each tail $=$ 1.64. Then using the sampling frame from each kebele, number of samples selected from each group was determined as (p) $(q)=$ Estimate of variance $=0.25$ (Maximum possible proportion $(0.5) * 1$ - maximum possible proportion (0.5) gave maximum possible sample size). $\mathrm{e}=$ Acceptable margin of error for proportion being estimated $=0.08$ (error researcher is willing to accept).

Data type, data collection method and data analysis

Both quantitative and qualitative data was collected. Semi structured interview schedule was used after it was pre-tested on a small sample of five respondents from members of beekeepers and seven from non-members of non-respondents. Quantitative data gathered using interview schedule from the beekeepers was analysed using SPSS version 20 Software and the data was analysed using descriptive statistics (mean, frequency, percentages, t-test, and chi square). Likewise, qualitative data gathered using FGD and Key informants interpreted using narration, content analysis and on spot analysis.

\section{RESULTS AND DISCUSSIONS}

The results of the study with summary statistics and explanation of the variables are displayed in Table 1 to5.

\section{Demographic characteristics of the respondents}

Age: At the time of the survey, the average age of the youth group and non-group beekeeper were 25.5 and 26.01old, respectively; the respondent's age was not significantly different for group members and non-groups (Table 1).

Gender: Evidence from Table 2 reveal that there were a higher number of females $(26.32 \%)$ in group of youths than that in non-group members, but the difference was not significant. The intention here was to consider the participation of youth female in beekeeping technology utilization as women play key role in most poverty reduction program.

Education: The study shows that $96.7 \%$ of the group members were educated whereas $17 \%$ of illiterate youth were a member of non-group. There is a significant difference in 
the years of schooling of the respondents among group members and non-group at $1 \%$ level of significance, with the former being more educated (Table 2 ). Given that education is an important factor to create a favorable mental attitude for acceptance of new technologies (Caswell et al, 2001).

Marital status: The majority of the study population was single $(76 \%)$ while $24 \%$ of them were married. None of the respondents replied divorced.

\section{Socioeconomic characteristics of the respondents}

Family size: The average family size of group members and non groups were 2.4 and 2.3, respectively (Table 1 ). However, there was no statistically significance difference. It implies that large or small family size does not affect participation of youths in beekeeping. The study is in line with Tamiru and $\mathrm{K}$ (2016) who reported that there is no association between family size of respondents and types of beekeeping engagement. Farm size: Likewise, the mean farm size to group members and non group was 0.25 and 0.26 acres and the difference in farm size is insignificant (Table 1 ). This indicates that farm size does not influence youths to participate in beekeeping enterprise in the study area. This is because beekeeping enterprise does not need productive large land unlike other farming activities. The study disagree with Alamu in Abdullahi et al (2012) who reported that farmers that had more land area were more likely to take advantage of new technology and innovations.

TLU: Livestock holding is an important indicator of household's wealth position in rural context. Table 1 show that the mean TLU owned by group members was 0.12 while that of non members was 0.14 . The result revealed that there is no significant variation in average livestock ownership between group and non-group beekeepers.

Beekeeping Income: Group members had significantly higher average income from beekeeping enterprise than non group (at 5\%) during the survey time (Table 1 ). This is due to the provision of improved beekeeping technology package (training, improved management practices, bee tools, etc) to group members that brought yield increment.

Income from other sources: Many beekeepers can earn additional income by engaging in various income sources. This is believed to raise their financial position during interim period since honey production is seasonal. The study shows that there is no significant variation in income from non beekeeping activity between group and non-group beekeepers.

Total honey harvested: The study result reveals that the average honey yield obtained by individual members of group was $75 \mathrm{~kg}$ from their backyard bee hives while those of non group harvested $43.56 \mathrm{~kg}$ annually (Table 1 ). It shows that group members had harvested honey at $1 \%$ of significance level than those non group members. It signifies that being a member of youth beekeeping enterprises help them acquire beekeeping knowledge to apply at their home garden individually besides group.

Total number of bee colony: The average number of bee colonies managed by each youth members and non members were nine and four, respectively. There was statistically significance difference between group and non group in terms of number of bee colonies owned by each beekeeper at $1 \%$ level of significance (Table 1 ). This indicated that taking part in youth producer group encourage them to increase bee colonies for maximum honey yields through colony multiplication. Furthermore, low initial investment to operate transitional chefeka hive for honey production help them double bee colonies.

Table 1: Summary statistics of the sample respondents for continuous variables $(\mathrm{N}=105)$

\begin{tabular}{lllllll}
\hline Variable & $\begin{array}{l}\text { Group } \\
(\mathrm{n}=57)\end{array}$ & \multicolumn{3}{c}{$\begin{array}{c}\text { non group } \\
(\mathrm{n}=48)\end{array}$} & $\begin{array}{c}\text { T- } \\
\text { value }\end{array}$ \\
& Mean & SD & Mean & SD & \\
Age & 25.5 & 3.12 & 26.01 & 2.972 & 3.3 \\
Family size & 2.4 & 0.53 & 2.3 & 0.42 & 4.24 \\
Farm size & 0.25 & 0.012 & 0.26 & 0.03 & 5.32 \\
TLU & 0.12 & 0.29 & 0.14 & 0.35 & 4.62 \\
Beekeeping income (USD) & 625 & 2.31 & 375 & 1.25 & $2.2^{* *}$ \\
Income from other & 66.67 & 15.14 & 65.75 & 17.25 & 6.15 \\
sources (USD) & & & & & \\
Total honey harvested & 75 & 12.5 & 44 & 10.25 & $4.16^{* * *}$ \\
(kg) & & & & & \\
Total of colony owned & 9 & 4.3 & 4 & 3.5 & $2.32^{* * *}$ \\
\hline
\end{tabular}

Note: ${ }^{* * *},{ }^{* *}$, and ${ }^{*}$ indicates that the factor is significant at $1 \%, 5 \%$ and $10 \%$ level of significance, respectively.

\section{Institutional factors}

Beekeeping training: The study shows that $100 \%$ of youth group members participated in improved beekeeping technologies compared to non group members. The chi-square result shows statistically significant difference at $1 \%$ significant level between group members and non members with respect to youth beekeepers contact with extension agent (Table 2 ). In other words the proportion of beekeeping technology user is higher among training participants than nonparticipants.

Awareness: Awareness on the technologies and its benefit helps the beekeeper to learn more about the technologies and motivates the beekeepers to-wards adopting the technology. Among the respondents, $100 \%$ of youth group members had got an opportunity to aware/hear about the technology but $54.27 \%$ of non-group not (Table 2 ). It is statistically significantly different at $\mathrm{p}<0.01 \%$. This shows that the youth beekeepers that got a chance of having information on the technologies benefit more.

Honey processing skill: Respondents were asked whether they can thoroughly extract crude honey into pure honey or not. The result shows that all of group members able to harvest ripen honey and process into pure one while $64.5 \%$ of non group member cannot (Table 2 ). The chi-square 
result shows that there was statistically significance difference between group members and non-group members with respect to honey processing skills at $1 \%$ significance level.

Colony transferring: Survey respondents were asked the question "Can you independently transfer bee colonies from traditional hive onto improved one?" Results in Table 2 shows all group members have confident enough to transfer while $77.1 \%$ of non members do not have sufficient skill to undertake transferring of bee colonies. The chi-square result shows statistically significant difference at 5\% significant level between group members and non members with respect to youth beekeepers bee colonies transferring skills

\section{Hive Acquisition According to Group}

Communal land for apiary site establishing was secured at both districts (Figure 2C). Table 3 shows higher number of bee colonies managed by Derartu honey producer group compared to Agaro honey producer group. Producer group at Mana district named their group Derartu because Derartu Tullu was the first black African women to win an Olympic gold medal in 1992-draping the Ethiopian flag across her shoulders. The groups show zeal to make history win unemployment which lowers their moral and dignity.

Moreover, gradual increase in transitional chefeka beehives number (63 to 101) happened because of benefits derived from it while decrease in traditional bee hives that they inclined towards transitional beekeeping (Table 3 ). Transitional Chefeka beehives were preferred by youth group relative to movable frame hive because of its low cost and accessories. Currently, in Ethiopia, the cost of movable frame hive ranges from $65-69 \$$ which is not affordable to low income youth. High proportion of youth in the study area confirmed that, they got their establishing colonies by catching swarms (hanging bait hives on the apex of trees) followed by inheritance or gift from parents. This result is in line with Kiros and Tsegay (2017) who reported that the majority of beekeepers started out by catching swarms. This might be due to the fact that the area is endowed with species of plants that are favored to bees.

Group formation and strengthening was intended to clearly define group norms, encourage youth fellowship development, experience the power of synergy, and establish roles and responsibilities assigned to members for common benefits. Hence, training in business plan development, entrepreneurship, group governance and record keeping was
(Table 2 ).

Experience sharing : Table 2 shows that the proportion of youth group members participated in beekeeping experience sharing was higher $(75.44 \%)$ compared to non-participants of experience sharing $(81.25 \%)$. The chi-square result shows that there is statistically significance difference between participants and non-participants of experience sharing on their beekeeping development at $1 \%$ significance level. This is because experience sharing allows individuals to observe how the new ways of doing beekeeping develop confidence on the practice.

Table 3: Distribution of beehives across groups across honey season in the area

\begin{tabular}{llllll}
\hline \multirow{2}{*}{ District } & Group name & \multicolumn{2}{l}{ August, 2017 (\%) } & \multicolumn{2}{l}{$\begin{array}{l}\text { Since December, } \\
2018(\%)\end{array}$} \\
& & $\begin{array}{l}\text { Tradi- } \\
\text { tional }\end{array}$ & $\begin{array}{l}\text { Transi- } \\
\text { tional }\end{array}$ & $\begin{array}{l}\text { Tradi- } \\
\text { tional }\end{array}$ & $\begin{array}{l}\text { Transi- } \\
\text { tional }\end{array}$ \\
Goma & $\begin{array}{l}\text { Agaro honey } \\
\text { producer }\end{array}$ & 33 & 22 & 21 & 36 \\
Mana & $\begin{array}{l}\text { Derartu honey } \\
\text { producer }\end{array}$ & 59 & 41 & 27 & 65 \\
Total & & 92 & 63 & 48 & 101 \\
\hline
\end{tabular}

Source: Own survey, 2019

\section{Beekeeping training and group dynamics of youth groups}

Preliminary needs assessment of rural youths' interest was conducted. Besides, the most prevalent beekeeping practices constraints faced by rural youth like lack of knowledge to utilize transitional Chefeka bee hive, bee colony transferring from traditional onto improved bee hives, active and dearth period management practices, post-harvest honey handling techniques, lack of bee protective cloths and tools as well as market problems were identified. Then, training techniques that back up knowledge and skill development was employed for 57 youths (Figure 2 A). In order to make theoretical parts more understandable to the youths, pictorial facts were displayed using power point, poster, flip charts, video shows and success experiences on improved beekeeping. Further below beekeeping training topics were delivered through establishing facilities and training materials for the group members for five days (Table 4 ) by apiculture senior researchers.

organized. It provided groups committees with business skills, ability to seek for existing opportunity, administrative skills, mobilize resource, and resource management skills as well as problem solving skills as training was supported by hands-on activity. 
Table 2: Summary statistics for sample respondents for categorical variables (N=105)

\begin{tabular}{|c|c|c|c|c|c|}
\hline Variable & $\begin{array}{c}\text { Group }(\mathrm{N}=57) \\
\text { in } \%\end{array}$ & $\begin{array}{c}\text { Non group }(\mathrm{N}=48) \\
\text { in } \%\end{array}$ & Total & Chi square & $\mathrm{p}$-value \\
\hline \multicolumn{6}{|l|}{ Sex } \\
\hline M & 73.68 & 77.08 & 75.23 & \multirow{2}{*}{1.218} & \multirow{2}{*}{0.269} \\
\hline F & 26.32 & 22.3 & 24.76 & & \\
\hline \multicolumn{6}{|l|}{ Education } \\
\hline Illiterate & 3.51 & 16.67 & 16.67 & \multirow{5}{*}{$1.2^{* * *}$} & \multirow{5}{*}{0.000} \\
\hline Grade 1-4 & 9.30 & 27.08 & 83.33 & & \\
\hline Grade 5-8 & 15.00 & 22.9 & & & \\
\hline Grade 9-12 & 43.45 & 20.8 & & & \\
\hline Higher & 29.82 & 12.5 & & & \\
\hline \multicolumn{6}{|l|}{ Marital } \\
\hline Single & 85.4 & 64.58 & 76.19 & \multirow{3}{*}{0.44} & \multirow{3}{*}{0.912} \\
\hline Married & 14.6 & 35.42 & 23.81 & & \\
\hline Divorced & 0 & 0 & & & \\
\hline \multicolumn{6}{|l|}{ Training } \\
\hline Yes & 100 & 10.42 & 59.05 & \multirow{2}{*}{$1.009^{* * *}$} & \multirow{2}{*}{0.000} \\
\hline No & 0 & 89.58 & 40.95 & & \\
\hline \multicolumn{6}{|l|}{ Awareness } \\
\hline Yes & 100 & 45.83 & 77.14 & \multirow{2}{*}{$8.83^{* * *}$} & \multirow{2}{*}{0.000} \\
\hline No & 0 & 54.16 & 22.85 & & \\
\hline \multicolumn{6}{|l|}{ Honey processing } \\
\hline Yes & 100 & 35.4 & 67.61 & \multirow{2}{*}{$13.2^{* * *}$} & \multirow{2}{*}{0.000} \\
\hline No & & 64.5 & 32.38 & & \\
\hline \multicolumn{6}{|l|}{ Colony transferring } \\
\hline Yes & 100 & 22.9 & 64.76 & \multirow{2}{*}{$23.6^{* *}$} & \multirow{2}{*}{0.023} \\
\hline No & & 77.1 & 35.23 & & \\
\hline \multicolumn{6}{|l|}{ Experience sharing } \\
\hline Yes & 75.44 & 18.75 & 49.52 & \multirow{2}{*}{$16.23^{* * *}$} & \multirow{2}{*}{0.000} \\
\hline No & 24.56 & 81.25 & 50.48 & & \\
\hline
\end{tabular}

Source: Own survey, 2019

Table 4: Basic beekeeping training organized for youth beekeeper groups in Goma and Mana districts

\begin{tabular}{llll}
\hline Topics & Hours & Topics & Duration \\
Introduction to beekeeping practices & $6: 00$ & Seasonal bee management practices & $4: 00$ \\
Bee botany and ecology & $4: 00$ & Apiary site improvement & $1: 00$ \\
Bee biology & $3: 00$ & Chefeka hive construction (practical) & $4: 00$ \\
Simple colony multiplication & $4: 00$ & Bee colony transferring (practical) & $2: 00$ \\
Bee health & $3: 00$ & Processing crude honey and bees wax (practical) & $4: 00$ \\
How to start beekeeping for income generation & $2: 00$ & Bee tools making, hive stand making & $3: 00$ \\
\hline
\end{tabular}




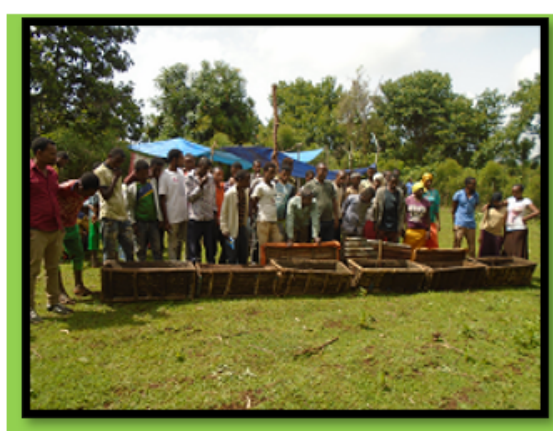

Practical Training (A)

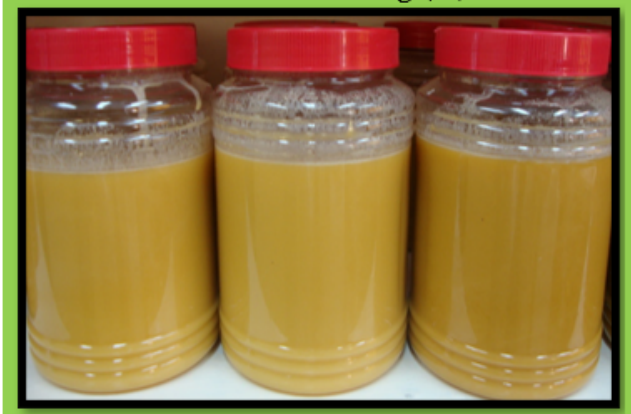

Packed pure honey (D)

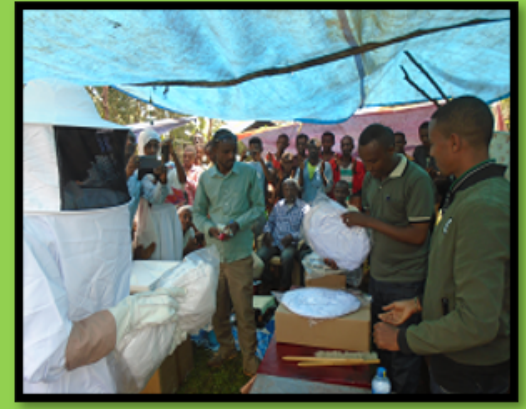

Beekeeping tools provision (B)

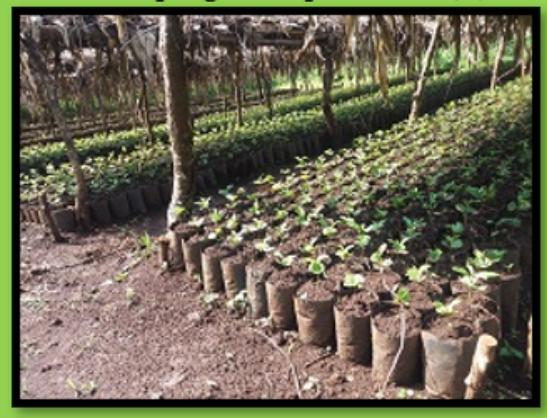

Coffee seedling nursery (E)

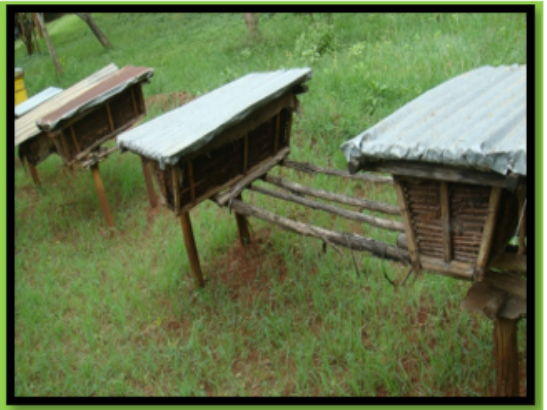

Apiary site (C)

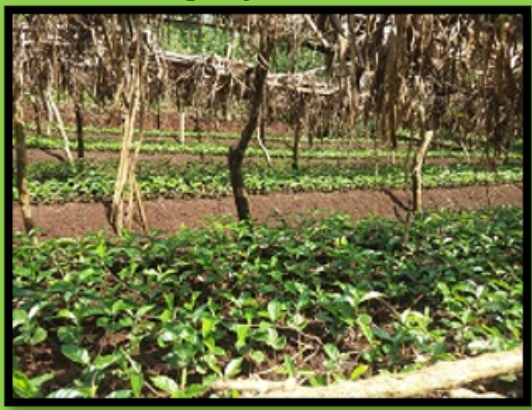

Coffee seedling nursery(E)

Fig. 2: Improved beekeeping packages to income diversification of youth in the study area

Furthermore, each group was frequently contacted in order to validate that group formation would be strong enough and effective against assumption indicated in the project. In order to further strengthening group to continually operate their business, refreshment training targeted on honey and bees wax marketing and business skill was provided for each group members.

Materials and tools like crude honey presser, smoker, honey strainer, bee veil, bee suit, hand glove, and queen excluder were expensive, in accessible to youth beekeepers and unfamiliar with them, and these materials might not be donated freely as a gift but to experience youth group the advantages of these tools while engage in beekeeping enterprise and marketing as well as encourage them to use it (Figure 2 B).

Youth groups also engaged in income diversification to increase their income from beekeeping sector. Producer groups provide honey extracting service at affordable price to the surrounding beekeepers. It has dual benefits (1) additional income from the rent of honey presser (2) community benefited from the availability of the tools in their residence. 'Yes indeed, what innovative intervention its!' They also collect honey and beeswax from the community to derive benefit from it.

Honey buyers were assessed to identify their demand on honey products, and they lack means to get producers who produce quantity and quality honey. Then, market linkage established to overcome market problem through bringing together honey producers and buyers. Finally, honey buyers satisfied at honey quality and quantity while producers happy with honey prices.
Moreover, gradual increase from revenue accruing from honey harvest encouraged youth groups to start new venture, coffee seedling production, side by side to earn additional income as Coffee growing provides substantial income to smallholder farmers. Goma and Mana districts are one of the most coffee potential are in the country. For this each group raised 50,000 coffee seedlings and earn 2000USD in the third year of project life (Figure $2 \mathrm{E}$ ). Coffee production has strong impact on per capita consumption expenditure among the smallholders.

\section{Quantity of honey yield and income from transitional}

\section{Chefeka beehive of communal}

With traditional beekeeping practices, productivity of honeybee is quite low per (5-6 kg on average) traditional hive but intermediate hives can yield more (10-15 kg on average) but less than frame hive (15-20 kg on average). Following training, close follow up was conducted to check whether or not groups undertaking improved beekeeping management against assumptions indicated in the project. 
Table 5: Honey yield and income obtained by producer groups $(\mathrm{N}=57)$

\begin{tabular}{lllll}
\hline Season & \multicolumn{2}{l}{ Yield in kg } & \multicolumn{2}{l}{ Income in USD } \\
& Honey & Bees wax & Honey & Bees wax \\
& 416 & 37 & 1576.64 & 292.3 \\
August, 2017 & 1080 & 97.75 & 4093.2 & 840.65 \\
$\begin{array}{l}\text { December, } \\
2018\end{array}$ & & & & \\
Total & 1,496 & 134.75 & 5669.84 & 1158.85 \\
& & & \multicolumn{3}{l}{ Grand total 6828.69 } \\
\hline
\end{tabular}

Source: Own Survey, 2019

On average 17.4 kilogram of honey per year from transitional Chefeka hives was harvested by groups. This result was in agreement with the result reported by Kiros and Tsegay (2017) who found that the average honey yield per year/colony was $16.2 \pm 0.62 \mathrm{~kg}$ for transitional hive. During August, 2017, 416 $\mathrm{kg}$ of honey and $37 \mathrm{~kg}$ of bee wax obtained. Revenue generated encouraged the groups increase colony number in double fold and able to produced $1080 \mathrm{~kg}$ of honey and $97.75 \mathrm{~kg}$ of bees wax in December, 2018. In sum 1,496 kg of honey and $134.75 \mathrm{~kg}$ of beeswax which estimated to earn a sum of 5669.84USD (US Dollar) and 1158.85USD was obtained, respectively (Table 5 ). A unit $\mathrm{kg}$ of honey and beeswax from transitional Chefeka hive was 3.79USD and 8.6USD in the area respectively. On average hive productivity was increased from $6 \mathrm{~kg}$ to $17.4 \mathrm{~kg}$ due to taking up of improved beekeeping management practices in the area.

Furthermore, a sum of 367.93USD obtained from each group members hives kept at their backyards. This is because each individual was advised to establish at least two bee colonies at their backyard independently. Generally, a total sum of 7196.62USD obtained from transitional chefeka bee hive from August, 2017 to December 2018 (Figure 2 D). As a result, youth income was increased which was indispensable revenue they had never attained before the intervention. We can prove that, beekeeping intervention started brought income improvement in the livelihoods of the jobless rural youth, in short period.

\section{Transitional Chefeka bees hive and forest conservation}

Chefeka bee hive is transitional bee hive made from nontimber local materials which is cheap and affordable to poor farmers unlike movable frame hive and Kenya Top Bar hive. It

\section{REFERENCES}

Abdullahi A, Baba KM and Ala AL. 2012. Economics of resource use in small-scale ricproduction: a case study of Niger state. Nigeria. International journal of AgriScience 2(5):429-443.

Ahmad DF, Sr J and Gurung MB 2007. Beekeeping and rural development (Kathmandu, Nepal) 36-36.

Ahmad F and Pratap U 2009. rban Labor Markets in Ethiopia: Challenges and Prospects. Volume I: Synthesis report 38665 World Bank: Poverty Reduction and Economic Management Unit Africa Region. does not encourage cutting down of economically important trees (cordia africana, gravilia robusta, etc) for hive construction. Cutting down tall trees can cause biodiversity loss and habitat destruction through destroy of other trees and organisms that can support ecological balance. However, the role of using chefeka hive to preserve forest trees is invaluable. Finally, it's recognized that use of Chefeka for honey production that improves livelihood of poor group can be served as adaptation strategy to combat recurrent climate change. Besides, chefeka hive is affordable which costs 2.26 USD unlike Movable frame hive and Kenya top bar hives (KTB) costs about 71.43USD and 42.86USD, respectively. Members were used to cut down and sell economically important trees for furniture and other purposes. Now they vowed to stop it totally.

\section{CONCLUSIONS}

This paper has described the positive impact that beekeeping can have on the lives of rural youths. Recognizing the contribution of beekeeping to the livelihoods of pro-poor, beekeeping can be used as the tool in creating job opportunities to transform vulnerable people into secured life, and the communities are aware of the value of bees in forest conservation and the need to safeguard them.

Beekeeping can therefore be considered a viable enterprise and protective measure which can be integrated into national forestry. Unemployed youth income empowerment may not be realized with one year. Strengthening out growers to continue further viable venture found to be very important. Hence, the project terminated by directing some strategies to youth groups for further profit. These are; established market linkage between producers and buyers, handover the whole activities to be supported by respective districts concerned bodies, maintain savings and expand beekeeping activities. Therefore, development interventions better to combine efforts to transforming youths' vulnerability into security through sustainable extension services.

\section{ACKNOWLEDGMENT}

I kindly thank International Development EnterpriseEthiopia (iDE) for providing research grant. My thanks also extend to beekeepers in the study area for willing to giving us all relevant data.

Anonymous 2007. Urban Labor Markets in Ethiopia: Challenges and Prospects. Volume I: Synthesis report 38665 World Bank: Poverty Reduction and Economic Management Unit Africa Region.

Caswell M, Fuglie KO, Ingram C, Kascak JS and C 2001.

Chazovachii B, Chuma M, Mushuku A, Chirenje L, Chitongo L and Mudyariwa R. 2012. Livelihood Resilient Strategies through Beekeeping in Chitanga Village, Mwenezi District, Zimbabwe. Sustainable Agriculture Research 2(1):124-124. url: https://dx. doi.org/10.5539/sar.v2n1p124. doi: 10.5539/sar.v2n1p124 
Dorosh and S E 2010. The Rural-Urban Transformation in Ethiopia (Addis Ababa, Ethiopia).

IPMS 2007. Gomma Pilot Learning District Diagnosis and Program Design (Addis Ababa, Ethiopia) 85-85.

Kiros $\mathrm{W}$ and Tsegay $\mathrm{T}$ 2017. Honey-bee production practices and hive technology preferences in Jimma and Illubabor Zone of Oromiya Regional State, Ethiopia. url: https://dx.doi.org/10. 1515/ausae-2017-0003. doi: 10.1515/ausae-2017-0003

Mcs L and Machangu JS. 2008. Analysis of Beekeeping Rotential in Income Generation and Coastal Forest Conservation in Lindi Region. Tanzania. Asian Journal of African Studies 24:85-107.

Nuru A, Hepburn HR and Radloff SE. 2002. Induction of propolis production byApis mellifera bandasiiin traditional basket and Langstroth movable-frame hives in Ethiopia. Journal of Apicultural Research 41(3-4):101-106. url: https://dx.doi.org/10.1080/
00218839.2002.11101076. doi: 10.1080/00218839.2002.11101076

Nzinga H, Gebrekidan BT and T 2012. Youth Unemployment: Ethiopia Country Study. Working paper: International Growth Centre, London School of Economic and Political Science (Houghton Street, London WC2A 2AE) .

Singh P, Singh KM and Shahi B. 2016. Role of Honey Bee Pollination in Quality Seed Production of Cauliflower for Scalingup of Livelihood in Vaishali District of Bihar. Journal of AgriSearch 3(2):115-118. url: https://dx.doi.org/10.21921/jas. v3i2.11271. doi: 10.21921/jas.v3i2.11271

Tamiru JD and K. 2016. Factors affecting honey production in Ambo district, West Shewa Zone, Oromia Regional State. Ethiopia. International Journal of Economics and Business Management 2(2):170-182. 